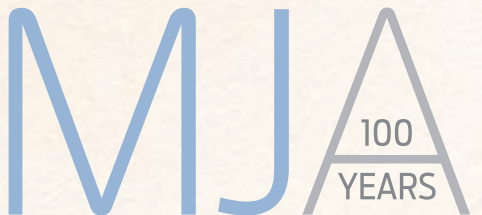

The Medical Journal of Australia • 1914-2014 www.mja.com.au

Editor-in-Chief

Stephen Leeder, AO, MD, FRACP

Deputy Editors

Tatiana Janusic, MB BS, DPH, FRACGP

Wendy Morgan, MB ChB, MPH(Hons), FRACGP

Astika Kappagoda, MB BS, MPhil, PhD

Robyn Godding, MB BS, MPH, FRACMA

Christine Gee, BSc(Med), MBBS(Hons)

Diana McKay, FRANZCP, MHM, AFRACMA

Deputy Editor, Poetry and Fiction

Leah Kaminsky, MB BS, BA

Senior Assistant Editors

Elsina Meyer, BSc

Katherine McLeod, BSc(Hons)

Assistant Editors

Christine Binskin, BSC

Suzanne Habjan, BSc(Hons), PhD

Olivia Wroth, BVSC

Graeme Prince, BAppSc, BA(Hons), MA(Hons)

Sonya Chervonsky, BA

Scientific Proofreaders

Gita Sankaran, BSc, MIM, PhD

Kathryn Tuckwell, MB BS, BA(Hons)

Librarian Jackie Holman, BAComm(Info)

MJA Journalist/Careers Editor Cate Swannell, BA

Editorial Administrator Kerrie Harding

Editorial Assistant Zane Colling

Production Glenn Carter, Peter Humphries

\section{Electronic Publishing}

Peter Hollo, BSc(Hons), BA, LMusA

Ross Sandoval, BComp

Publishing Assistant Wade Clarke, BAComm

\section{CONTACT THE MJA}

AMPCo House, 277Clarence Street, Sydney,

NSW 2000 ABN 20000005854.

Post: The MJA, Locked Bag 3030, Strawberry Hills,

NSW 2012. Tel: (02) 9562 6666. Fax: (02) 95626699.

mja@mja.com.au

INSTRUCTIONS TO AUTHORS: https://www.mja.

com.au/journal/mja-instructions-authors

ADVERTISING AND COMMERCIAL REPRINTS

Sales and Marketing Manager David Kelly

Commercial Manager Delores D'Costa

Bus Dev \& Senior Account Manager Mike Mata

Account Manager Sarah Lander

Advertising Coordinator Susantika Susantika

Tel: (02) 95626621.

advertising@mja.com.au, reprints@mja.com.au

\section{SUBSCRIPTIONS Jane Anderson}

Tel: (02) 9562 6617. subscriptions@mja.com.au

2014 Annual subscription (+ GST):

Individual: RRP A $\$ 410.00$ (new), A $\$ 350.00$ (renewal).

Institutions: on application.

The Medical Journal of Australia (MJA) is published on the lst and 3rd Monday of each month by the Australasian Medical Publishing Company Proprietary Limited (AMPCo), a wholly

owned subsidiary of the Australian Medical Association (AMA).

The statements or opinions that are expressed in the MJA

reflect the views of the authors and do not represent the

opinions or policies of the MJA or the AMA unless so stated.

None of AMPCo, the AMA or any of its servants and agents will

have any liability in any way arising from information or advice

that is contained in the MJA. Although all accepted advertising

material is expected to conform to ethical and legal

standards, such acceptance does not imply endorsement by

the MJA. The MJA is intended for medical professionals and is

provided without warranty, express or implied.

All literary matter in the MJA is covered by copyright, and must not be reproduced, stored in a retrieval system, or transmitted in any form by electronic or mechanical means, photocopying, or recording, without written permission.

(c) AMPCo, 2014 - Printed by Webstar Australia.

\begin{tabular}{|c|c|}
\hline 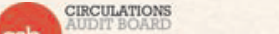 & Member of \\
\hline $\begin{array}{l}30,074 \text { circulation as at } \\
30 \text { September } 2013 \cdot 155 \mathrm{~N}: 0025-729 \mathrm{X}\end{array}$ & PublishersAustralia \\
\hline
\end{tabular}

\title{
Highlights from our archives
}

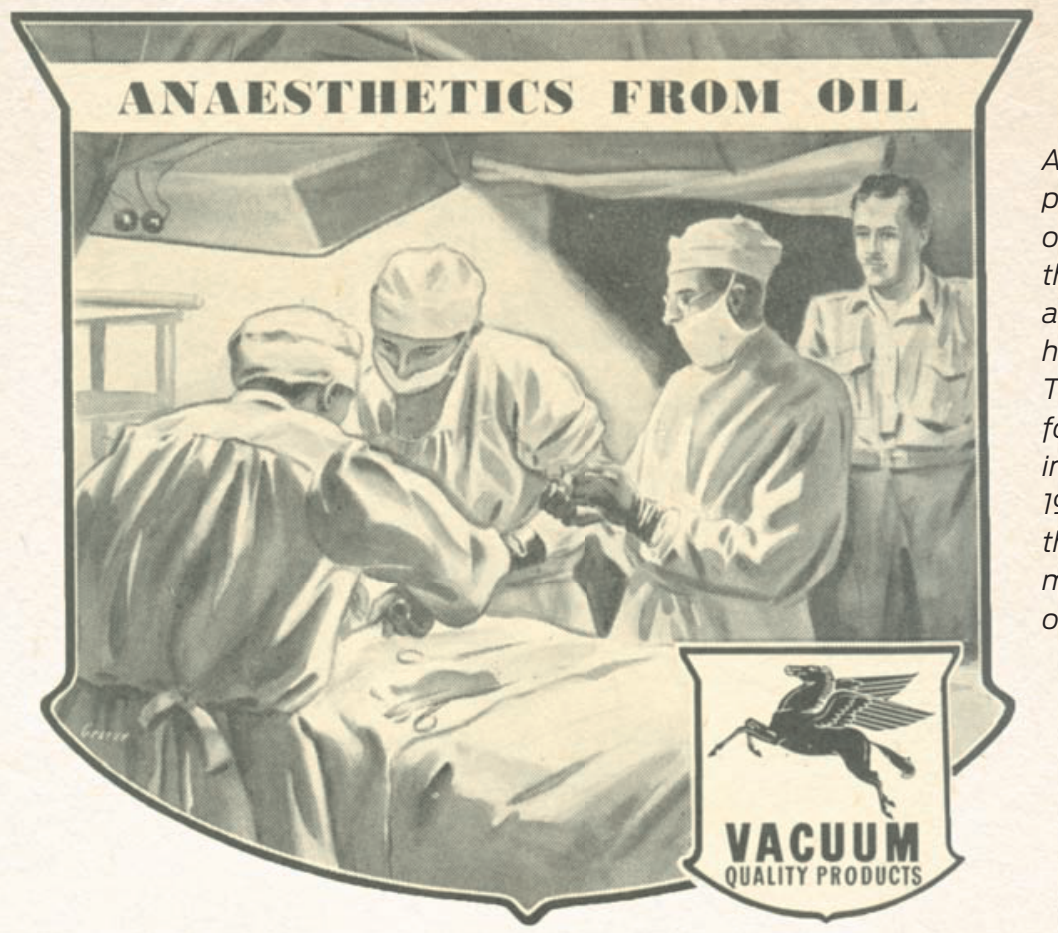

As World War II progressed, most of the advertising in the MJA reflected a common goal to help the war effort. This advertisement for an oil company, in the 9 September 1944 issue, highlights the military and medicinal benefits of the product.

\section{Why glorify murder?}

SIR: Recently a Sydney commercial station broadcast "The Sacred Flame", a play of evil influence, in which the plot revolved around a murderess (an elderly mother), the victim (her incurable invalid son paralysed after crashing), his errant wife - pregnant to her paramour (the invalid's brother), a nurse and the family doctor. The play - well produced and very well acted - finished on a note of conspiracy between doctor, nurse, murderess (a poisoner at that?) and all concerned to hush up the deliberate murder - all apparently in the cause of sacred flame of "love".

Subversive of all ideals of British law and justice, unethical, unchristian and pagan, it was a sorry business, and one cannot congratulate those who chose the play for public entertainment, nor the authorities who passed it for general broadcast. Since the first world war there have been many
British mothers, wives and sisters who have become devoted "slaves" to their permanently incurable invalid men, and after this war there will be many more. In fact, since the "blitz" on England, one might add husbands to the list who will gladly care for their incurably crippled wives. One can imagine the tortured feelings of permanently invalided service personnel when listening to this broadcast.

The play also was a mephitic slander on the medical profession and on the noble women who for years before and after Florence Nightingale have ornamented the nursing profession, and would tend to lessen public confidence in these professions. Recently a public inquiry was held concerning the effects of "horror films" on impressionable children. Why strain at the gnat when a camel of this size is allowed to pollute the air?

Kevin Byrne NSW 26 November 1943

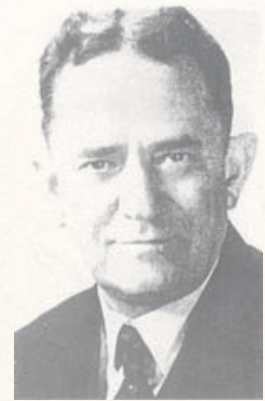

\section{Party man}

Dr Mervyn Archdall was the second editor of the MJA, serving from the death of Henry Armit in 1930 until his retirement just before his own death in 1957. His leading articles were published in two volumes, In pursuit and In pursuit: II. Awarded the Gold Medal of the British Medical Association for outstanding service to medicine and the medical profession, Dr Archdall was known for his "love of parties and simple fun, and his dislike of anything insincere or sanctimonious", according to the Roll of the Royal Australasian College of Physicians. 